\title{
The Effect of Teaching Method and Lecture Program ON STUDENTS' SATISFACTION RATES AND ACADEMIC ACHIEVEMENT
}

\author{
Tomo Djudin \\ Universitas Tanjungpura, Pontianak, Indonesia \\ E-mail:tomo.djudin@yahoo.com
}

\begin{abstract}
This research examined the effect of teaching method and lecture program on student satisfaction rate and academic achievement of physics education department of Education and Teacher Training (FKIP) of Tanjungpura University, Pontianak. The descriptive method with the causalcomparative study was employed in this research. The sample was (232) respondents of fifth semester in academic year 2016/2017 which drawn by using unproportioned stratified random sampling technique. A questionnaire of lecturer academic service satisfaction was administered. Based on data analysis, the findings of this research are: (1) There is a significant difference of student's satisfaction rate with lecturers' academic service $(t=5.455, \mathrm{p}<0.05)$ and academic achievement $(t=4.149, \mathrm{p}<0.05)$ in terms of lecture method and direct instruction model. The students who having received direct instruction show higher on statisfaction rate and academic achevement than who having received lecture method; (2) There is a significant main effect of the lecture program on the rate of student satisfaction $(\mathrm{F}=30.346, \mathrm{p}$ < $0.05)$ and on students academic achievement $(F=15.646, p<0.05) ;(3)$ There is no significant interaction effect of the teaching method and lecture program on student satisfaction rate $(\mathrm{F}=0.753, \mathrm{p}>0.05)$ and academic achievement $(\mathrm{F}=0.326, \mathrm{p}>0.05)$. It recommends that an institution should undertake internal survey to explore student satisfaction with academic services periodically.
\end{abstract}

Keywords: Satisfaction Rate; Academic Achievement; Main and Interaction Effects

\section{INTRODUCTION}

The new paradigm of higher education management stated that a university is service institution (Hidayat, 2004). Therefore, the teachinglearning process is not only can be assumed as the relationship between students and educators, but also the relationship between the recipient and the service provider (Tjiptono,2004). Student satisfaction rate is one of indicators of the success of educational institutions in performing its functions. According to Ivancevies in Maria Ulfa (2009), students are the main customers to be served. The success of a college is characterized by the quality of service provided. Quality of services can be identified through student satisfaction. Alves and Raposo (2009) argued that institutions can also benefit from student satisfaction in several other ways; for example, satisfied students are less likely to drop out, and more likely to achieve higher grades.
Student satisfaction has become an important concept in higher education because students are paying higher tuition fees and increasingly seeing themselves as customers and is commonly used as an indicator of quality by quality assurance agencies (Xiao \& Wilkins, 2015; Hamid \& Pihie,2004). Dill and Soo (2005) confirmed that students are the key stakeholders in higher education and their opinion is important in improving the quality of higher education reputation and images of universities.

Student satisfaction rate has strong relation to quality of academic services of lecturers. The more quality of service quality, the higher of student satisfaction rate. Student satisfaction is essential in Total Quality Management (Helgesen \& Nesset, 2007). Therefore, a college or university must identify the needs of the students carefully and try to satisfy by assuming that students as the main customers to be served (Allred \& Swenson, 2006; Bigne, Moliner \&Sanchez, 2003). 
Several previous studies that explored students satisfaction with academic services have been conducted by students (Dewi \& Asikin, 2009; Setiawan, 2013; Noermijati, 2010; Ulfa, 2009), lecturers (Husnayetti, 2012; Alves \& Raposo, 2009), and institutions (Gusti, 2008; Juniarti \& Sany, 2012). Hery Susanto (2014) in Setiawan (2013), for example, concluded that the quality of academic services which consist of tangible, reliability, responsiveness, assurance, and empathy aspect has a significant simultaneously effect on student satisfaction rate. The National Accreditation Board (BAN) of Higher Education confirmed that university is obliged to explore students' satisfaction comprehensively with academic services (Hidayat, 2004). However, just a few (current) studies that analysis students satisfaction rate with academic services of educators and academic achievement regarding lecture program and teaching method.

In the context of this study, Faculty of Teacher Training and Education (FKIP) Untan Pontianak has 2 (two) lecture programs, they are; S-1 Regular and S-1 Nonregular. One of the study programs available is physics education. The students have been received academic services of lecturers regarding the use of teaching method in or outside the classroom. The teaching methods which lecturers commonly used in fifth semester of academic year 2016/2017 are lecture method and direct instruction. The other teaching methods are excluded in this study.

In higher education, customer satisfaction begins with the expectations upon the quality of the teaching staff or lecturer (Helgesen \& Nesset, 2007). However, which teaching method effective in learning environment in higher education, even with decades of research, has yet to be resolved (Chua \& Heng, 2014). Until now, a systematic effort to explore the students' satisfaction rate regarding lecture program and teaching method has never undertaken by the institution. The contextual and current issues as mentioned above bear on a rational consideration for carrying out this study. The main purpose of this study is to examine the main and interaction effect of teaching method and lecture program on students satisfaction rate and academic achievement.

\section{LITERATURE REVIEW}

\section{A. The Definition of and Factors affecting Customer Satisfaction}

The definition of customer satisfaction is not easy to formulate. James G. Barnes (2001) in Ulfa (2009) stated that customer satisfaction, in fact, is a response which given by the customer for the fulfillment of their needs to gain comfort. Satisfaction is a person's perception of something that has met his expectations. The assessment of customer satisfaction associated with the fulfillment of a need, including the fulfillment of customers needs and their expectations as well.

According to Susan Fournier and David Glen Mick (1989) in Alves and Raposo (2009), customer satisfaction; (1) is a dynamic process, (2) has a strong social dimension, (3) contains an integral component of meaning and emotion, (4) has contextual and interconnected processes between different paradigms, models with modes, and (5) is the product which always related to life satisfaction and quality of life itself.

Customer satisfaction is temporary and varied in manners. Customer satisfaction is temporary because what is felt "satisfied" in one situation, does not necessarily to be satisfied with another situation. Similarly, to satisfy one customer in responding to the advantages or privileges of a product in the same situation is not similar to another customer. It means that customer satisfaction depends on the characteristic of customers and the situations (Rivai, 2005).

According to Kotler (2002), customer satisfaction is affected by many factors; they are: 1) value-added services, 2) views of products or services, 3) business aspects, and 4) shocks that can provide emotional stimulation. The main factor that can influence customer satisfaction is the interaction between producers or companies and customers who have a comfortable response or perception of a product. This interaction can be identified in 5 levels which will involve more interpersonal contact with employees and service providers, they are: 1) core products or services, 2) supporting systems and services, 3) technical performance, 4) elements of interaction with customers, and 5) emotional elements affective dimension of service.

\section{B. Techniques for Assessing Customer Satisfaction}

There are several techniques or methods that a company can use to measure and monitor its customers. Kotler (2002) identified four methods for measuring customer satisfaction:

1. Complaints and Suggestions System. A company or institution have to provide speed and convenient access for its customers to communicate their suggestions, criticisms, opinions, and complaints. The information gained through this method can provide new ideas and valuable inputs for the company to respond quickly and quickly the problems occurred.

2. Ghost Shopping. One way to get an idea of customer satisfaction is to hire some Ghost Shopping to play or pretend to be a potential customer of a company's products and competitors. They are asked to interact with service providers and use the company's products or services. Based on their experience, they are then asked to report their findings regarding the strengths and weaknesses of the company's 
products and competitors.

3. Lost Customer Analysis. A Company should contact customers who have stopped buying or have moved their suppliers to understand why it happened and in order to take further improvement or refinement policies.

4. Customer Satisfaction Survey. Through the survey, the company will get responses and feedback directly from customers and also give a positive impression that the company is paying attention to its customers. Measuring customer satisfaction through this method can be done in various ways, including; 1) Directly Reported Satisfaction; 2) Derived Satisfaction; 3) Problem Analysis; 4) Importance-Performance Analysis.

C. Student Satisfaction with Academic Services

Student satisfaction with academic services of lecturers might be characterized by 5 (five) dimensions, namely: tangible, reliability, responsiveness, assurance, and empathy (Kotler, 2002; Tjiptono, 2004; Hamid \& Pihie, 2004).

The first dimension of service quality is tangible. Tangible is a physical dimension. A service cannot be smelled, and cannot be touched so that physical evidence becomes essential as a measure of service. Tangible is the ability to provide physical facilities and adequate lecture equipment regarding the appearance of lecturers and public facilities, for example, the availability of infrastructure facilities. Students will assess quality of learning from all facilities and facilities available.

The second dimension of satisfaction is reliability, a dimension that measures the reliability of higher education in providing services to students. There are two aspects of this dimension: (1) the ability of the lecturer to provide the instructional method as promised and (2) how far the lecturer provides accurate learning. Reliability is the ability of lecturers in providing learning in accordance with the promised (on time), with immediate, relevant and accurate so as to satisfy the students.

The third dimension of satisfaction is responsiveness, which is the dynamic dimension of service quality. Responsiveness is the willingness of the lecturers to help and provide learning according to the needs of students. This dimension appears in situations where lecturers are easily found for consultation purposes. The student's expectations of the accuracy of the service will always change from time to time.

The fourth dimension of customer satisfaction is assured. The quality of assurance dimension relates to the behavior of teaching staff or lecturers in instilling trust and confidence to the students. Assurance includes competence, knowledge, skills, decency. An example of this dimension is shown as the attitude of lecturers who deliver lectures in accordance with their respective areas of expertise. Lecturers seek to gain insight by reading, attending seminars, training, or conducting research. There are four aspects of the assurance dimension: friendliness, competence, credibility, and security.

The last dimension of satisfaction is empathy. Empathy is a lecturer's attitude in providing wholehearted services, such as personal attention and understanding that each student has different abilities and needs. This attitude can be demonstrated by understanding the role of lecturer not only as an educator but also as a counselor and supervisor. This dimension is related to Maslow's theory of human development needs. Human needs are not just physical, security and social needs, but also the needs of ego and self-actualization. These two latent needs are much related to the dimension of empathy (Wagiran, 2012).

\section{METHODOLOGY}

The descriptive method with causal comparative (ex-post facto) study was employed in this study (Creswell, 2008; Ferguson, 1976). The sample consists of 232 respondents who are students of the fifth semester of academic year 2016/2017 which was drawn by using unproportioned stratified random sampling technique. Some respondents = amount of students physics program $x$ subjects which students attend in the same semester. In this research, the teaching method is grouped into lecture method and direct instruction. The lecture method is characterized by explaining, discussing, and assigning tasks of content subject. Direct instruction is characterized by explaining, giving examples of problems, giving models how to solve problems, provide feedback, and assign tasks. The (nominal) data of teaching method that lecturer applied during teaching learning process was obtained from the interview with the students.

The (nominal) data of lecture program and (interval) data of student academic achievement is gathered from the total score of summative examination $(U A S)$ which is documented at Subdivision of Student Academic and Administrative Affairs $(S U B B A A K)$. The (interval) data of student satisfaction rate is collected by using a questionnaire of satisfaction with academic services of the lecturer that consist of tangible, responsiveness, reliability, assurance, and empathy aspect (adopted from A E.Setiawan (2013)). The difference of mean scores of student satisfaction rate and academic achievement is analyzed by using $t$-test. The main and interaction effect of factors (lecture program and teaching method) are analyzed by using $F$-test, two-way ANOVA (Wahana Komputer, 2009; Ferguson, 1976). 


\section{IV.RESULTS AND DISCUSSION}

A. Results

1. Differences of Student Satisfaction Rate in terms of Lecture Program and Teaching Method

The overall mean score of student satisfaction with academic services of lecturers in terms of lecture program and teaching method and results of compare means are shown in Table I.

Table I

The Result of Compare Means of Student Satisfaction Rate

\begin{tabular}{|c|c|c|c|c|c|}
\hline \multirow{2}{*}{ No } & \multirow{2}{*}{\multicolumn{2}{|c|}{ Independent Variable }} & \multicolumn{3}{|c|}{ Student Satisfaction Rate } \\
\hline & & & Mean & $t$ & sig \\
\hline \multirow{3}{*}{1} & \multirow{3}{*}{$\begin{array}{l}\text { Lecture } \\
\text { Program }\end{array}$} & Regular & & \multirow{3}{*}{-0.013} & \multirow{3}{*}{0.989} \\
\hline & & & 56.19 & & \\
\hline & & Nonregular & 56.20 & & \\
\hline \multirow[t]{2}{*}{2} & \multirow{2}{*}{$\begin{array}{c}\text { Teaching } \\
\text { Method }\end{array}$} & $\begin{array}{l}\text { Lecture } \\
\text { Method }\end{array}$ & 55.26 & \multirow[t]{2}{*}{$-5.455^{*}$} & \multirow[t]{2}{*}{0.000} \\
\hline & & $\begin{array}{l}\text { Direct } \\
\text { Instruction }\end{array}$ & 56.61 & & \\
\hline
\end{tabular}

From Table I, research findings are as follows:

a. There is no significant difference of student satisfaction rate with academic services of lecturers in terms of lecture program (S-1 Regular and Nonregular) ( $p>0.05)$.

b. There is a significant difference of student satisfaction rate with lecturers academic service in terms of teaching method (lecture method and direct instruction $(\mathrm{p}<0.05)$. Students' satisfaction rate with academic services of lecturers who have received direct instruction is higher than who have received lecture method.

2. Differences of Student Academic Achievement in terms of Lecture Program and Teaching Method

The mean scores of student academic achievement in terms of lecture program and teaching method and results of compare means are shown in Table II.

Table II

The Result of Compare Means of Student Academic Achievement

\begin{tabular}{|c|c|c|c|c|c|}
\hline \multirow{2}{*}{ No } & \multirow{2}{*}{\multicolumn{2}{|c|}{ Independent Variable }} & \multicolumn{3}{|c|}{ Student Academic Achievement } \\
\hline & & & Mean & $t$ & sig \\
\hline \multirow{3}{*}{1} & \multirow{3}{*}{$\begin{array}{l}\text { Lecture } \\
\text { Program }\end{array}$} & Regular & & \multirow{3}{*}{0.400} & \multirow{3}{*}{0.989} \\
\hline & & & 73.91 & & \\
\hline & & Nonregular & 73.37 & & \\
\hline 2 & $\begin{array}{l}\text { Teaching } \\
\text { Method }\end{array}$ & $\begin{array}{l}\text { Lecture } \\
\text { Method } \\
\text { Direct } \\
\text { Instruction }\end{array}$ & $\begin{array}{r}71.91 \\
77.62\end{array}$ & $-4.149 *$ & 0.000 \\
\hline
\end{tabular}

From Table II, research findings are as follows: a. There is no significant difference of student academic achievement in terms of lecture program (S-1 Regular and Nonregular) ( $p>0.05)$.

b. There is a significant difference of student academic achievement in terms of teaching method (lecture method and direct instruction ( $\mathrm{p}$ $<0.05$ ). Students' academic achievement who have received direct instruction is higher than who have received lecture method.

From Table I and Table II, the results indicate that only teaching method has significant effect on students satisfaction rate and academic achievement.

\section{Main and Interaction Effect of Lecture Program and Teaching Method on Student Satisfaction Rate}

By using two-way ANOVA, the results of main effect and interaction effect of lecture program and teaching method on student satisfaction rate are shown in Table III.

Table III

Result of Main and Interaction Effect on Student Satisfaction Rate

Dependent Variable : Student Satisfaction Rate

\begin{tabular}{|c|c|c|c|c|c|}
\hline Source & $\begin{array}{c}\text { Sum Square } \\
\text { Tipe III }\end{array}$ & $\mathrm{df}$ & $\begin{array}{c}\text { Mean } \\
\text { Square }\end{array}$ & $F$ & Sig. \\
\hline $\mathrm{X} 1$ & 0.556 & 1 & 0.556 & 0.182 & 0.670 \\
\hline $\mathrm{X} 2$ & 92.587 & 1 & 92.587 & $30.346^{*}$ & 0.000 \\
\hline $\mathrm{X} 1 * \mathrm{X} 2$ & 2.299 & 1 & 2.299 & 0.753 & 0.386 \\
\hline
\end{tabular}

From Table III, research findings are as follows:

a. There is no main effect of X1 (lecture program) on student satisfaction rate with academic service of lecturer $(\mathrm{sig}=0.670, \mathrm{p}>0.05)$.

b. There is a significant main effect of factor X2 (teaching method) on student satisfaction level with academic service of lecturer ( $\mathrm{sig}=0.000, \mathrm{p}<$ 0.05). This means that there is a significant difference of student satisfaction rate with the academic services of lecturers in terms of the lecture model.

c. There is no significant interaction effect of $\mathrm{X} 1 * \mathrm{X} 2$ factor on student satisfaction rate with academic service of lecturer $(\mathrm{sig}=0.386, \mathrm{p}>0.05)$. The result is consistent with the coefficient of relative contribution of $R$ squared that is just 0.094 or $9.4 \%$.

4. Main and Interaction Effect of Lecture Program and Teaching Method on Student Academic Achievement

By using two-way ANOVA, the results of main effect and interaction effect of lecture program and teaching method on student satisfaction rate as shown in Table IV. 
Table IV

Result of Main and Interaction Effect on Student Academic Achievement

\begin{tabular}{lccccc}
\multicolumn{7}{l}{ Dependent Variable : Student Academic Achievement } \\
\hline Source & $\begin{array}{c}\text { Sum Square } \\
\text { Tipe III }\end{array}$ & $\mathrm{df}$ & $\begin{array}{c}\text { Mean } \\
\text { Square }\end{array}$ & $F$ & Sig. \\
\hline $\mathrm{X} 1$ & 25.706 & 1 & 25.706 & 0.272 & 0.602 \\
$\mathrm{X} 2$ & 1477.235 & 1 & 1477.23 & $15.646^{*}$ & 0.000 \\
$\mathrm{X} 1 * \mathrm{X} 2$ & 30.809 & 1 & 30.809 & 0.326 & 0.568 \\
\hline \multicolumn{2}{l}{ a. $R$ Squared $=0.040$ (Adjusted $R$ Squared $=0.034$} &
\end{tabular}

From Table IV, research findings are as follows:

a. There is no main effect of factor X1 (lecture program) on student academic achievement ( $\mathrm{sig}=$ $0.602, \mathrm{p}>0.05)$.

b. There is a significant main effect of factor X2 (teaching method) on student academic achievement $(\mathrm{sig}=0.000, \mathrm{p}<0.05)$. This means that there is a significant difference of student academic achievement in terms of teaching method.

c. There is no significant interaction effect of $\mathrm{X} 1 * \mathrm{X} 2$ factor on student academic achievement ( $\operatorname{sig}=0.568, \mathrm{p}>0.05)$. This result is consistent with the coefficient of relative contribution of $R$ squared is just 0.040 or $4 \%$.

From Table III and Table IV, the results indicate that teaching method and lecture program have no significant interaction effect on students satisfaction rate and academic achievement.

\section{B. Discussion}

This study concludes that teaching method has significant main effect on students satisfaction rate and academic achievement. Students who have received direct instruction model show higher on satisfaction rate and academic achievement than who have received lecture method. The teaching method and lecture program have no significant interaction effect on students satisfaction rate and academic achievement.

It is mentioned that students satisfaction rate with academic services can be identified from many aspects, they are; tangible, reliability, responsiveness, assurance, and empathy. Wright's (1996) in Hamid and Pihie (2004) identified 8 major service quality factors for higher education: diversity of educational experience (diversity of course work and student body), access and use of facilities (location, atmosphere and hours of university facilities), personalized interaction (interaction between student and faculty), student quality (quality of students at the university), educational process requirements and ability to fulfil requirements), faculty quality (academic and professional background of faculty), and professor's years of teaching experience.
Hery Susanto in Setiawan (2013) reported that the quality of academic service consisting of tangible, reliability, responsiveness, assurance, and empathy have simultaneously a significant influence on students satisfaction rate with academic services. The study recommended that institution has to increase the professionalism and knowledge of employees and improvement of supporting facilities 000 as well.

Based on their study, Juniarti and Sany (2012) found that aspect of reliability will partially relative contribution to students satisfaction is $20.4 \%$, responsiveness is $13,3 \%$, assurance is $16,8 \%$, empathy is 20,2 5, and last aspect, tangible, is $19.3 \%$. Handayani, et.al (2003) reported that the readiness and mastery of the lecturers had having supported by the university by improving the quality of materials and teaching continuously. Up-dating information through the internet is very helpful for students to keep up with the developments on campus. The change of curriculum periodically in a better direction that makes students more confident in facing the challenges of the industrial world. Renovating physical facilities such as classroom airconditioned to provide a convenient learning atmosphere for students. Morton-Cooper (1993) in Hamid and Pihie (2004) notioned that in a research on lecturer traits valued by students cited responsiveness and trustworthiness as the major traits. Trustworthiness included the element of reliability and consistency. Lecturer enthusiasm was also a vital trait that encouraged learning.

Satisfaction is something personal. Each individual has different levels of satisfaction in accordance with the prevailing value system (Rivai, 2005). Thus it can be said that satisfaction is an evaluation that describes a person's feelings of pleasure or displeasure in the move. Tjiptono (2004) argued that customer satisfaction is the level of feeling in which a person expresses the result of comparison of the performance of the product or service received and expected A person with a high degree of satisfaction will indicate a positive attitude. On the other hand, a person who is not satisfied with his work indicates a negative attitude (Kotler, 2002).

Teaching methods play an important role in increasing student achievement. Haas (2002) concluded that teaching methods accounted for $9.7 \%$ variance in the average scores of students. Based on the meta-analysis, he found that the factors of teaching methods have a significant effect on student achievement. Teaching methods that are often applied in the learning process are direct teaching, problem-based learning, cooperative learning assisted technology, manipulative model, and some representations of communication and research results. He suggested that lecturers or teachers emphasize three different types of teaching methods, namely direct instruction, problem-based learning, 
and technology-aided instruction. He also argued that cooperative learning can encourage students to learn, improve academic achievement, increase student retention, improve student satisfaction with their learning experiences, help students develop skills in oral communication, social skills, and price increases student self.

Another powerful teaching method is direct instruction. Din 92000) in Yeoh, et.al (2012) defined direct instruction as an instructional sequence that includes demonstration, controlled practice with instruction and feedback, and self-directed exercise with feedback direct instruction when combined other instructional approaches and used appropriately, can both effectively and efficiently improve basic math skills in secondary schools. Chua and Heng (2014) confirmed that In an increasingly diverse teaching and learning environment today, there have been countless discussions and debates on the effectiveness of teaching in higher institutions of learning. Even with decades of research, the issue of effective teaching has yet to be resolved. In higher education, customer satisfaction begins with the expectations created upon the service by various parties to be delivered to or experienced by the customer. One of the expectations is the quality of the teaching staff (Helgesen \& Nesset, 2007).

The success of the academic process is characterized by the efficiency of the teaching and learning process, the level of student satisfaction with the learning process, and the success rate of the students in following the particular course. The efficiency of university teaching and student satisfaction levels has been the general focus of academic work (Yeoh, Yo, \& Chan, 2012; Juniarti \& Sany, 2012). Universities and educational institutions recognize the importance of maintaining the quality of the teaching and learning process. That is why educational institutions have many efforts to improve the quality of teaching and learning. Another seriousness in maintaining the quality of education by the authorities is evidenced by the requirement to prepare the quality of the guarantee system in every educational institution, especially in universities. Teacher profiles or teacher quality are of paramount concern to parents and policymakers. Profile of lecturer, according to Ackerman, et. al (2006) in Tella (2006), including training, experience, pedagogical practice, and professional development. Tella (2006) concluded that there was a correlation between teacher profile and student achievement. Clotfelter, et al. (2003) in Juniarti and Sany (2012) confirmed that teacher experience has a positive effect on student achievement. Harris and Tim (2007) concluded that more experienced teachers seem to be more effective at teaching basic math and reading in high school.

To gain effective teaching, according to Chua and Heng (2014), lecturers should be able to give clear presentation to assist the students in making sense of and absorb new knowledge and skills taught. Students would welcome lecturers who are able to present the material in a clear and logical sequence. The material presented must also be intelligible and meaningful to the students. It is important not to overburden them with too many main points in each lecture and not to use too many different types of presentation materials, which can confuse the learners.

Student participation or engagement should be encouraged in today's classroom. Through participation, students are more motivated, learn better, improved communication skills, and are better critical thinkers (Handayani, Yermias \& Ratminto, 2003). Allred and Swenson (2006) reminded that lecturers should recognize the importance of student participation and reduce dependence on teachercentered teaching methodologies such as lecture method, which restrict students' engagement in the lesson. In fact, the traditional lecture-only format is losing its prevalence in the classroom today. Instead, it has been replaced with mixed delivery method such as group discussion, peer review to minimize lecturing. In class, participation has become increasingly important today especially among millennial generation students who demand more interaction from their classroom experience.

This study concludes that there is no significant interaction effect of lecture program and teaching method on students satisfaction with the academic services of lecturers and student academic achievement. From tracing of previous researches, I found that there were few studies that test or analyze the interaction effects of two variables on more than two dependent variables. Most researches were conducted to examine the effects of multiple factors using multiple correlations, multiple regression equations, and path analysis. Therefore, this findings might be assumed a novel finding This finding is supported by result of previous study which concludes that there is an interaction between entrance factor and lecture program in influencing student academic achievement (Aswandi, 2016). Juniarty and Sany (2012) concluded that the level of student satisfaction is significantly influenced by many factors in addition to faculty profiles, academic achievement, and teaching methods.

\section{CONCLUSION AND SUGGESTIONS}

\section{A. Conclusions}

Relevant to the research questions and results of data analysis, the conclusions are as follows:

1. The teaching method has significant main effect on students satisfaction rate and academic achievement. 
2. The lecture program has no significant main effect on students satisfaction rate and academic achievement.

3. The teaching method and lecture program have no significant interaction effect on students satisfaction rate and academic achievement.

B. Suggestions

Based on the research findings, some recommendations are launched as follows:

1. The results of the study contribute to add to the sparse or non-existent literature related to lecturers' teaching effectiveness in faculty. Further research using a bigger population scale should be conducted to add to this body of knowledge. It would be interesting for future researchers to also investigate lecturers' teaching effectiveness that goes beyond academic responsibilities in the classroom, such as research publications and participation in academic conferences, workshops, and seminars.

2. The questionnaire used to explore student satisfaction with lecturer academic services which developed in this study can be adopted by developing more items of each aspect of satisfaction. The institution should undertake an internal survey to explore student satisfaction. Future research can be done to find out which aspects of satisfaction seemed has the strongest influence on student academic achievement.

\section{ACKNOWLEDGEMENT}

I declare that this work is original, not duplicate publication, and has not been published elsewhere. I am sure that this research article is primarily concerned with education issues (teaching and learning in particular) and relevant to the aims of this journal.

\section{REFERENCES}

Allred, C.R., \& Swenson, M.J. 2006. Using technology to increase student preparation for and participation in marketing courses: The random selector model. Marketing Education Review, vol.16, pp.15-21.

Alves, H., \& Raposo, M. 2009. The measurement of the construct satisfaction in higher education. Services Industries Journal, vol.29, no.2, pp. 203-218.

Aswandi. 2016. Analisis prestasi akademik mahasiswa Universitas Tanjungpura ditinjau dari jalur seleksi masuk (SNMPTN, SBMPTN, dan Mandiri) dan program kuliah (S-1 Reguler dan Nonreguler). Laporan Penelitian. Universitas Tanjungpura.
Bigne, E., Moliner, M.A., \& Sanchez, J. 2003. Perceived quality and satisfaction in multiservice organizations: The case of Spanish public services. Journal of Services Marketing, vol.17, no.4, pp. 420-442.

Chua, C.L., \& Heng, R.K.K. 2014. Students' ratings of teaching effectiveness: What do students tell us about their teacher education lecturers?.[online].Avaiable.http:/www.iced20 14.se/proceedings/1536_Chua\%20POSTER.p df.

Creswell, J.W. 2008. Educational Research: Planning, Conducting and Evaluating Quantitative and Qualitative Research ( $3^{\text {rd }}$ ed). Boston: Pearson Prentice Hall.

Dewi, N.R., \& Asikin M. 2009. Kepuasan mahasiswa terhadap proses perkuliahan di FMIPA UNNES. Jurnal Lembar Ilmu Kependidikan, vol. 39 , no. 2 .

Dill, D., \& Soo, M. 2005. Academic quality, league tables, and public policy: A cross-national analysis of university ranking systems. Journal of Higher Education, vol.49, no.4, pp. 495-533.

Ferguson, G.A. 1976. Statistical Analysis in Psychology and Education ( $4^{\text {th }}$ edition). Tokyo: Mc-Graw Hill Kogakusha Ltd.

Gusti, I. 2008. Analisa kepuasan mahasiswa terhadap proses belajar mengajar di Program Diploma III FE UNUD. Buletin Studi Ekonomi, vol. 13, no.1, pp. 12-18.

Haas, M.S. 2002. The influence of teaching method on student's achievement on Virginia's End of Course Standards of learning test for algebra I. Dissertation. Virginia Polytechnic Institute and State University.

Hamid, J.A., \& Pihie, Z.A. 2004. Students' perception of the quality of teaching and learning in Business Studies Programs. Pertanika Journal Social Science and Humaniora, vol.12, no. 1, pp.71-86.

Handayani, R., Yermias, T.K., \& Ratminto. 2003. Analisis kepuasan pemakai terhadap pelayanan Perpustakaan Nasional Provinsi Daerah Istimewa Yogyakarta. Jurnal Sosiosains, vol. 17, no. 2, pp. 34-40.

Harris, D.N., \& Tim, R.S. 2007. Teacher training, teacher quality, and student achievement. National Center for Analysis of Longitudinal Data in Education Research, Working Paper.

Hidayat, D. 2004. Akreditasi, sertifikasi lembaga pendidikan dan kejuruan. Proceeding Makalah, 2004, Konvensi Nasional Aptekoindo II dan Temu Karya XIII FT/FPTK/JPTK Universitas/IKIP seIndonesia, Jakarta: 12 - 14 Februari 2004. pp. 88 . 
Husnayetti. 2012. Tingkat kepuasan mahasiswa dan proses belajar mengajar di Perguruan Tinggi STIE Ahmad Dahlan Jakarta. Jurnal Liquidity, Vol 1, No. 2, pp.115-124.

Juniarti \& Sany. 2012. Lecturer profile, student satisfaction rate and teaching method, its contribution to the passing rate.[omline].Avaiable:http;//www.academia. edu/lecturer_Profile_studen/7848356.

Kotler, P. 2002. Manajemen Pemasaran. Edisi Millennium (Terjemahan). Jakarta: Prenhallindo.

Noermijati. 2010. Kajian tentang kepuasan mahasiswa terhadap kinerja dosen di Fakultas Ekonomi UNIBRAW. Skripsi.

Rivai, V. 2005. Performance Appraisal (Sistem yang Tepat untuk Menilai Kinerja Karyawan dan Meningkatkan Daya Saing Perusahaan), Jakarta: PT. Raja Grafindo Persada.

Setiawan, A.E. 2013. Perangkat pengkuran tingkat kepuasan mahasiswa terhadap proses pembelajaran di jurusan Teknik Mesin Universitas Negeri Semarang. Skripsi. PMIPA.

Tella, A. 2006. Teachers variable as predictors of primary school pupil's academic achievement. presented at the $1^{\text {st }}$ African Conference on Universal Basic Education. University of Botswana.

Tjiptono, F. 2004. Manajemen Jasa. Edisi Ketiga. Yogyakarta: PT Andi.

Ulfa, M. 2009. Analisis Tingkat Kepuasan Mahasiswa Terhadap Kinerja Dosen Dalam Pembelajaran Pada Program Studi Pendidikan Ekonomi Universitas Riau. Skripsi. PMIPA.

Wagiran. 2012. Kepuasan mahasiswa jurusan pendidikan teknik mesin terhadap layanan akademik dan nonakademik. Laporan Penelitian. Fakultas Teknik UNY, 2012.

Wahana Komputer. 2009. Panduan Praktis SPSS 17 untuk Pengolahan data Statistik. Yogyakarta: C.V Ando Offset.

Xiao, J., \& Wilkins, S. 2015. The effects of lecturer commitment on student perceptions of teaching quality and student satisfaction in Chinese higher education. Journal of Higher Education Policy and Management, vol.37, no.1, pp. 98-110.

Yeoh, S.F., Yo, J.S., \& Chan, B.Y.F. 2012. Student evaluation of lecturer performance among private university students. Canadian Social Science, vol. 8, no.4, pp. 238-243. 